\title{
dosalgarves
}

\section{Effective interventions for micro and small enterprises to reach the preferable future of the Canggu area in Bali}

\section{Intervenções eficazes em micro e pequenas empresas para alcançar o futuro desejável na área de Canggu, Bali}

\author{
Inga Kludzeweit \\ Breda University of Applied Sciences, The Netherlands \\ i.kludzeweit@web.de \\ Thania Kamargiannis \\ Breda University of Applied Sciences, The Netherlands \\ thani.kamargiannis@googlemail.com

\section{Timoti Tirta} \\ Breda University of Applied Sciences, The Netherlands \\ timoti.tirta@gmail.com

\section{Ellis Middelkamp} \\ Breda University of Applied Sciences, The Netherlands \\ ellismiddelkamp@hotmail.com
}

\begin{abstract}
As tourist arrivals to Bali have increased steadily over the past 40 years, the crowds from Kuta and Seminyak have started to shift towards the now booming area of Canggu. Rapid developments present the community with the challenge of preservation vs. economic growth that will impact the destination's future. The objective of this study is to assess, analyze and evaluate the present and future situation of the Canggu area in order to give advice on the match between the area's supply and demand. The study provides Micro and Small Enterprises (MSEs) with recommendations on effective interventions in order to strengthen their strategic position to achieve the destination's preferable future. This study used four different research methods: desk research, participant observations, surveys with tourists, and semi-structured interviews with enterprises. Results show that the most impactful difference between MSEs lies in the level of strategy refinement, which suggests that creating a circular model between MSEs could strengthen the area of Canggu.
\end{abstract}

Keywords: micro and small enterprises (MSEs); sustainable development; tourism growth; Bali; Canggu.

Dos Algarves: A Multidisciplinary e-Journal, 36-2020.

ISBN 2182-5580 ๑ ESGHT - University of the Algarve, Portugal. 


\title{
Resumo
}

\begin{abstract}
À medida que o número de turistas, em Bali, foi aumentando, nos últimos 40 anos, os turistas, que visitavam Kuta e Seminyak, começaram a deslocar-se para Canggu, uma nova área em expansão. Estas tendências apresentaram à comunidade o desafio de preservação versus crescimento económico, que terá um impacto no futuro deste destino. O objetivo deste estudo é avaliar e analisar a situação atual e futura de Canggu, a fim de oferecer conselhos sobre o equilíbrio entre a oferta e a procura desta área. $O$ estudo fornece recomendações às micro e pequenas empresas (MPE), sobre intervenções eficazes, de modo a fortalecer a sua posição estratégica para alcançar um futuro desejável do destino. O estudo utilizou quatro métodos de recolha de dados: pesquisa bibliográfica, observação participante, inquéritos a turistas e entrevistas semiestruturadas a empresas. Os resultados mostram que a diferença mais notória, entre as MPE, reside no nível de sofisticação da estratégica, o que sugere que a criação de um modelo circular entre MPE poderia fortalecer a área de Canggu.
\end{abstract}

Palavras-chave: micro e pequenas empresas (MPE); desenvolvimento sustentável; crescimento turístico; Canggu.

\section{Introduction}

Tourist arrivals to Bali have increased steadily over the past 40 years (Government of Bali, 2010). Its rich and diverse culture, the friendliness of the inhabitants, natural beauty and spirituality have made Bali an attractive destination for many tourists with Kuta, Seminyak and Ubud as the main points of interest (Morgan \& Ver Berkmoes, 2017). Not even half a decade ago, the now booming village of Canggu was only known to a lucky few, but developments from the already crowded Seminyak have shifted over to the area of Canggu (Bali Tourism, 2017). Located on the coast of Southwest Bali, bordered by Seminyak in the south and Tanah Lot in the north, the town attracts an increasing amount of tourists, who come to eat and drink in one of the many restaurants as well as at health food outlets, emerge themselves in yoga exercises or go for a surf at one of the beaches the area has to offer. Especially in the past two years, the Canggu area has seen rapid developments and fast changes (Hewett, 2017).

The focal points of this report are Micro and Small Enterprises (MSEs) operating in the area. This study focuses on MSEs because in the observation process, the authors found that total amount of MSEs are the highest compared with the others. Depending on the country and the market structure, the definition of MSEs can vary. The report at hand uses an adjusted definition of Indonesian Ministry of Industry (2018). According to the Ministry, micro enterprises are enterprises employing a maximum of 10 people. Small enterprises employ from 11 up to a maximum of 30 people (Indonesian Ministry of Industry, 2018). However, interviewees mentioned that in some cases not all employees who work at an enterprise are actually on the payroll. This means an enterprise can have more employees working in real life than officially stated on paper. Therefore, a maximum of 40 employees is acceptable for the researchers' definition.

The goal of the paper at hand is to advise on effective interventions, which could help MSEs in the Canggu area to improve their competitive position in the future. In order to reach this aim, the study firstly focuses on the assessment of the current match between supply 
and demand in the Canggu area. This includes the area's attributes and assets, the attending markets as well as the destination's characteristics and developments. Secondly, a preferable future for MSEs in the Canggu area has been researched. Trends and outside influences that could pose a threat to this preferred future are taken into account, when strategic interventions to reach the future goal are being proposed.

\section{Research aim and research questions}

The aim of this study is to analyse, assess and evaluate the present and future situation of the Canggu area in order to give advice on the match between the area's supply and demand and to provide MSEs with advice on effective interventions in order to strengthen their strategic position to achieve the preferable future for the Canggu area.

The main research question that comes up when looking at the aim at the study is: Through which effective interventions can MSEs strengthen their strategic position in order to reach a preferable future for the Canggu area? Some sub questions that arise from the main research question are: (1) what is the current situation in Canggu? (2) what is the current strategic position of MSEs in Canggu? and (3) which internal and external factors impact Canggu?

\section{Methodology}

To reach the previously mentioned research goal, the present and future situation of the Canggu area had to be analysed, assessed and evaluated. Therefore, the report at hand uses the technique of triangulation (Salkind, 2010). Four different methods are utilized to collect and evaluate information for the analysis: desk research, (participant) observations, surveys with tourists (demand), and semi-structured interviews with Micro Small enterprises (supply). All methods were used simultaneously in order to support or undermine findings, or change the research focus at times.

The research was conducted done by a group of four researchers from the Netherlands, Indonesia and Germany. All researchers chose to be accommodated in several locations within the research area to gain the best familiarization possible and for convenient accessibility. The research group was separated in groups of two during the research process and collected secondary and primary data from the $9^{\text {th }}$ of April until the $2^{\text {nd }}$ of May 2018.

First, secondary data was collected through desk research. Online desk research was done by using search engines such as Google Scholar, and government published data.

Additionally, offline sources such as journal articles, newspaper articles, guestbooks in accommodation units and restaurants as well as statistics have been considered as secondary data. Desk research took place throughout the whole study to support the primary findings.

Furthermore, (participant) observations were done as an ongoing process throughout the study. First, the observations were conducted as a discovery of the area. Observations were conducted by taking notes of the situations that appeared. As the researchers did not reveal their identity, they became part of the situation or were able to observe the situation and take notes. The general infrastructure has been assessed as well as the structure of the 
supply and demand. Observations functioned as a method to assess the context, developments and to see which sectors and segments were active in the Canggu area. The structure of the supply has been visualized by mapping the observed stakeholders (initial stakeholders), further mentioned as the initial stakeholder map. This created the base for the interview guide. Furthermore, the structure of the demand has been visualized by drawing up an initial tourist profile. This functioned as a guideline for the tourist survey. The exploratory observations took place in the entire research area (Tibubeneng and Canggu) as well as outside of the research area (Kuta, Seminyak, Tanah Lot and further destinations along the coastline and inland) to be able to determine and draw the physical border of the study. Then, the goal of the second round of observations was to verify the obtained data from surveys and interviews.

In order to determine potential market segments, or the previously mentioned demand, within the area of Canggu, the market theory of segmentation by motivation has been applied. It is led by the thought that a heterogeneous group of tourists can be clustered into more homogeneous groups with similar consumption patterns (Rid, Ezeuduji \& PröbstlHaider, 2014). By grouping tourists according to underlying motivational push and pull factors, that influence the decision-making process and holiday preferences. It allows for a division of the overall market of Canggu into smaller segments, customize marketing, form strategies, and deliver tailor-made products. The questionnaire design aimed at determining underlying push and pull factors, age, nationality, travelling party and length of stay. Items to detect push and pull factors were designed on the basis of existing research and have been adjusted based on observations of the existing supply in the research area. Core assumptions that led the researchers to use this method have been that segmentation through socio-economic factors would not produce enough meaningful data to predict the tourism preferences in the Canggu area. Motivation and attitudes have, in this case, more explanatory power. To gain a better understanding of the push factors, participants have been asked to indicate the importance of factors such as participating in nightlife, healthy food and lifestyle, and sports activities when travelling, on a five point Likert-scale (1= not at all important, $5=$ =xtremely important). Similar items have been used to determine push factors, measuring the extent to which tourists have experienced activities such as nightlife, healthy food and lifestyle, and sports activities on a five point Likert-scale (1=not at all, $5=e x t r e m e l y)$. Using factor analysis in SPSS, natural groupings of items have been found, to see the relationship of the items. The questionnaires were handed out to 152 tourists, using the convenience-sampling method on three days from the $16^{\text {th }}$ till the $18^{\text {th }}$ of April at different times and locations during the days, where and when most tourists were present.

Finally, qualitative research was done with stakeholders by conducting 22 semistructured interviews. The interviewer and the informant engaged in an informal way, by means of an interview guide which allows adapting to individual processes within the conversation (Burgess, 1984). Relevant stakeholders were chosen by means of three methods. First, the most important stakeholders as "key players" in the research area were discovered by the researchers. This was achieved by doing desk research. Secondly, the "snowball-technique" was utilized, which is a method where current interviewees were asked for recommending possible further interviewees. It was applied for gaining 
information from the networking community of Canggu. Herewith a trust relationship between the interviewee and the interviewer could be built more easily. Third, a convenience type of sample was chosen. Enterprises were approached by their availability and willingness to participate at various locations in the Canggu area. Data was collected at different times of day and different days of the week over a period of 8 days ( $19^{\text {th }}$ until $27^{\text {th }}$ of April 2018) to increase the diversity of stakeholders. The research group formed teams of two to conduct the semi-structured interviews with enterprises. The internal stakeholder mapping by sectors and segments, which was based on observation, was utilized as a foundation to interview at least one stakeholder of each sector. A thematic analysis was performed in order to analyze the gathered qualitative data and themed into three categories: the innovators, the adapters and the survivors.

\section{Destination context}

The Canggu area is a village area in the Badung regency, located in the southwest of Bali. The main road in the Canggu area is Jalan Raya Canggu, which connects the inland area with the beach through smaller roads. Since the Canggu area has only been in growth since 2016, it still has some accessibility and transportation issues. Also, from observations in comparison with Kuta and Seminyak, Canggu can still be seen as uncrowded. Physically, Canggu is still dominated by rice fields and nature. However, the growth in the past two years has been rapid, which has brought many new buildings and construction sites upon, that will cause a decrease of rice fields in the future.

Additionally, as mentioned by interviewees 7, 8 and 15, the increased taxation of rice fields will enhance that effect. Furthermore, Canggu is known as one of the major surfing spots in Bali. Echo Beach and Batu Bolong beach are the most common locations for surfing (Figure 1). Also, through observations it was seen that a high number of yoga schools and organic cafés can be found in Canggu.

Figure 1. Map of the Canggu area

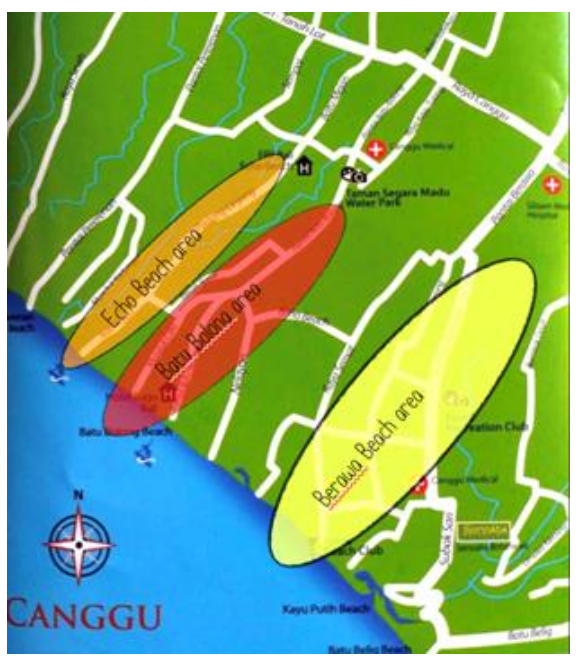

Source: Author's own drawing. 
Besides the physical development related to tourism, Canggu is well represented by the banjar. In total, 20 banjar were found in the research area. A banjar is a social and cultural community with the aim to preserve the Balinese culture. Also, the banjar collect plans for the tourism development in their area, as an input for the village and governmental master plans. Overcrowding and the loss of culture are aspects that are high on the agenda of the banjar, to which rules and regulations are connected, in order to limit and to control developments in the future. Within this situation, enterprises are required to engage with the community and the banjar and to follow certain governmental and traditional rules. Finally, Canggu is an area that is known for its social media activities. Social media is an aspect that is taken into consideration and often is crucial in a marketing strategy.

According to observations and data obtained from interviews 18 and 20, residents who have lived in the Canggu area for a long period of time, the developments of the Canggu area can be described. In the past, between 1983 and 2006, the first tourists came to the Canggu area to surf. They stayed in Kuta or Seminyak and just spent the day in the area. There were just a few accommodation units and other tourism facilities. Some years later, after 2006, locals started to set up small individual enterprises to offer tourism facilities, such as food and beverage. The first changes happened in 2006, when some residents sold and rented out their lands to foreigners and Indonesians from outside Bali. Even though the real development did not start yet, this was the start of it in the Canggu area. Tourism kept growing in Bali, but mainly in the Kuta and Seminyak area.

From 2013, the first real developments started to come into the Canggu area. Locals and foreigners started to compete in the tourism market, which was at that time still slowly increasing. The biggest increase started from 2015. In the past 3 years, the Canggu area has grown into a developing destination with a great deal of tourism facilities. It has become very popular for surfing, yoga and its café culture. The first major developments took place in Berawa, but currently, Batu Bolong can be described as the most developed area, which became clear within the observations. In Batu Bolong, there are many tourism related businesses and the first chain hotels have entered the area. The second developed area is Echo Beach, which is dominated by restaurants, hotels and co-working spaces. Thirdly, Berawa is on the list, showing some tourism facilities, although it is not dominated by tourism yet. Also, local businesses and restaurants still can be found. The other areas in the Canggu area can be considered as underdeveloped and residential; dominated by rice fields and nature. Finally, Raya Canggu is the main road, that is home to many enterprises which are not (directly) related to tourism.

\section{Findings}

All stakeholders of a destination take part in creating the tourism product and are part of the tourism supply. Due to the large number of MSE's, an initial grouping of those businesses was made on in order to create an interview guide, to assess the current match between supply and demand and finally to be able to see possible interaction patterns between 
businesses. The researchers grouped MSEs on basis of the sector and part of the supply side they are operating in (Figure 2).

Figure 2. Initial stakeholder mapping

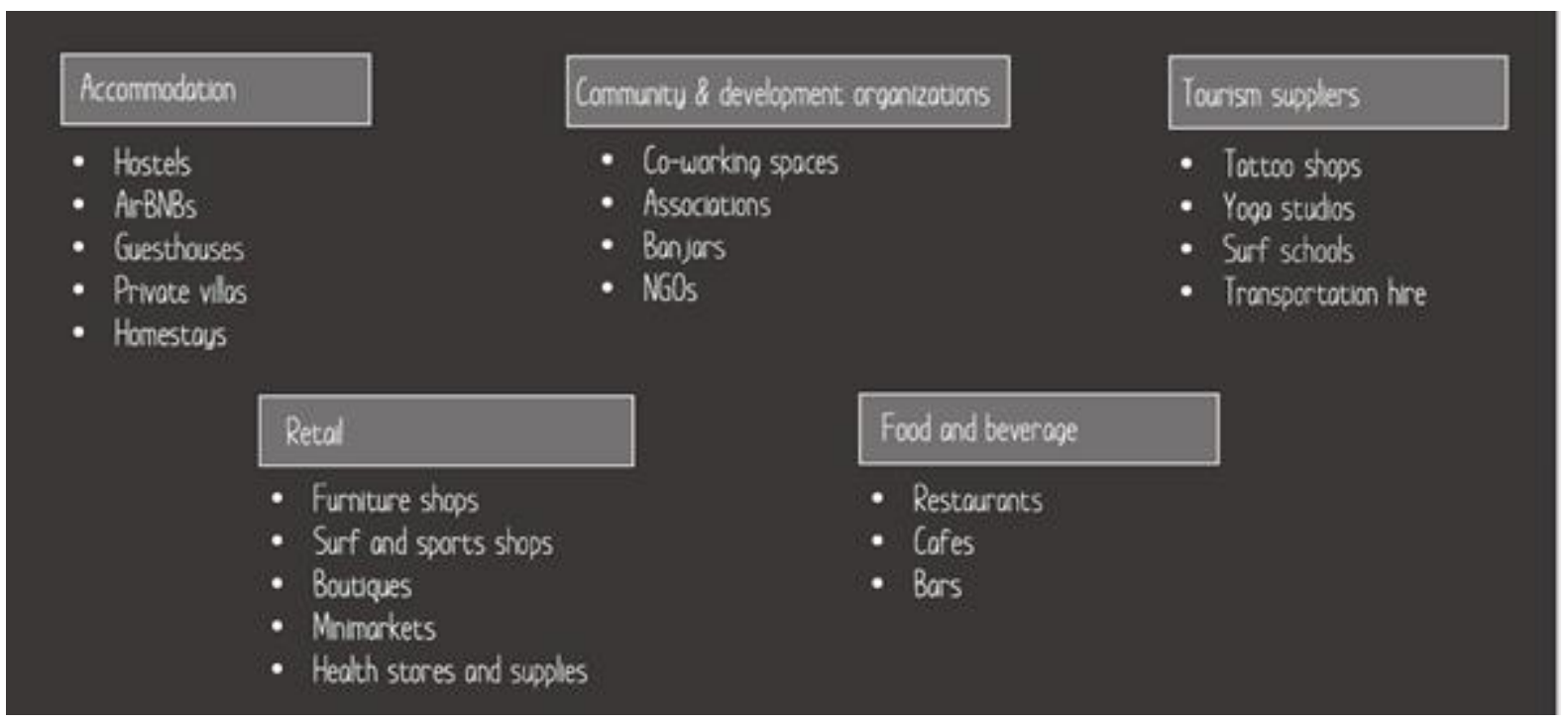

During and after the interview process, it became clear to the researchers that mapping stakeholders per sector alone does not represent the variety of businesses entirely. The interviews showed that similarities between enterprises operating in different sectors can at times - be larger than similarities within the same sector. The research outcome shows that the most impactful difference between MSEs in the Canggu area lies in the level of strategy refinement. It is important to note that no judgment should be passed on the importance of the stakeholder groups on basis of their strategy. All acting groups are vital for the creation of the tourism product and, together, provide the supply for the tourism needs in the Canggu area. Nevertheless, the researchers decided to categorize MSEs as follows.

MSEs who fall into the category of innovators are characterized by a well-thought through strategy, economic knowledge, and - in large part - financial literacy. Furthermore, entrepreneurs who operate innovative businesses have a deep understanding for the market and tourism needs, which allows them to react to changes in the environment and current trends in a fast pace: to a large extent they are owned or operated by foreigners. Interviewees who have been characterized as innovative often mentioned that they do intensive market research and try to get a feel of what works and what does not. An example for this can be seen in the behaviour of interviewee 8. Prior to opening up her own business, the interviewee attempted to gain knowledge of tourists needs by closely observing their everyday behaviour in the close environment to the location of her establishment. Based on these observations, the interviewee then created a fitting business strategy. Another interviewee mentioned that for him it is crucial to collect feedback about the food he offers 
in order to adjust his menu weekly. Innovators did not see the high number of competitors as a threat for their own business. Interviewee 3 told the researchers that in his opinion, competition can only help one to redefine and reinvent oneself. Even businesses who took over ideas from innovators are not seen as a threat. In many cases, Innovators function as an inspiration for those businesses who belong to the bracket of adapters. Although six interviewees have been characterized as innovative entrepreneurs, they represent the smallest number of businesses.

The researcher grouped those businesses as adapters, who have a very basic strategy. Often, this strategy is characterized by copying trends innovators implemented or set already. When market changes happen, they, unlike innovators, need more time to react to changing tourism needs. Operators of these businesses consist of foreign owners and local owners. Enterprises who have been characterized as adapters are aware of certain trends but the process of implementation of a new strategy takes long and is mainly led by innovators or obvious market changes. For example, one interviewee described, that he was aware of the need for social media to promote one's business in the Canggu area. He has not worked with it much yet, but is planning to use it in the future.

Survivors are the type of businesses who are and have been operating without a defined strategy. Often, these businesses are locally-owned. Some have been the first business to operate in their field in the area of Canggu and therefore have extensive knowledge about the local culture, traditions, and the area in general. Many of these businesses have been operating for a long period of time. This indicates that owners and managers of these businesses must have had a right approach in some way or profited from the fact that up until a few years ago, there was not much competition in the area and the development has been slow and stable. When asked about future strategies, all the interviewees had in common that there was no, very little or unfeasible planning. One interviewee mentioned that she does not know how to create a strategy and finds it difficult to find one. Another interviewee told the researchers that there is no strategy she will apply at all. Rapid growth and market changes might pose a threat to these businesses. Like the adapters, survivors see competition as a possible danger to their own businesses.

In order to understand what tourism destinations need to offer, it is important to know the demand side in depth. The major method to evaluate this was a tourist survey. On top of that informal interviews and participant observation were conducted. Furthermore, semistructured interviews with stakeholders gave insights into the demand side.

As mentioned in the methodology, this research has used a questionnaire as a survey method to obtain information about the existing demand in the Canggu area. The results of the questionnaire can be divided into three major findings: the demographics, the motivation to travel (push factors) and the activities tourists took part in (pull factors).

First, almost half of the respondents, $41 \%$, were staying in the Canggu area for more than 7 nights. Therefore, it can be stated that tourists in the Canggu area are long-stay visitor and not day visitors. When looking at the age of the respondents, the age range of the majority of the respondents is between 20 and 36 years. When looking at the nationalities of tourists, most respondents currently reside in Germany (13.1\%), Australia (11\%), the Netherlands (9.6\%), the United Kingdom (8.2\%), the United States (7.5\%), France (6.2\%), Indonesia and Russia 
(both $4.8 \%$ ). The majority of the respondents are female (63.1\%) and 36.9\% are male. Finally, most tourists are travelling by themselves within the Canggu area, followed by traveling with friends and traveling with partner.

After analyzing the demographics of the respondents, the motivation to travel, or the so-called push factors, were analyzed through a factor analysis in SPSS. In the factor analysis, the items of the questionnaire that showed a relationship to one another are grouped. From this analysis, five groups of tourists were categorized, all with their own characteristics and activities (Table 1). The first group of respondents has the commonality of taking part in sports activities and enjoying the sun and water. The second group has the characteristics of sharing experiences through social media and going shopping. The third group has enjoying landscape, nature and local culture in common. Then, the fourth group participate in nightlife and meeting new people. Finally, the fifth group enjoys healthy food and lifestyle and takes time for themselves.

Table 1. Groups of tourists with their motivation to travel

\begin{tabular}{|l|l|l|l|l|}
\hline $\begin{array}{l}\text { Group 1 } \\
\text { - Taking part in } \\
\text { sports activities } \\
-\begin{array}{l}\text { Enjoying the sun } \\
\text { and water }\end{array}\end{array}$ & $\begin{array}{l}\text { Group 2 Sharing experiences } \\
\text { through social media } \\
\text { - Going shopping }\end{array}$ & $\begin{array}{l}\text { Group 3 Enjoying landscape } \\
\text { and nature } \\
- \text { Enjoying local } \\
\text { culture }\end{array}$ & $\begin{array}{l}\text { Group 4 } \\
- \text { Participating } \\
\text { in nightlife } \\
- \text { Meeting new } \\
\text { people }\end{array}$ & $\begin{array}{l}\text { Group 5 } \\
- \text { Enjoying healthy } \\
\text { food and lifestyle } \\
\text { Taking time for } \\
\text { themselves }\end{array}$ \\
\hline
\end{tabular}

Finally, the activities tourists took part in, or the so-called pull factors, are analyzed the same way as the push factors. Through the factor analysis, activities that show a relationship between one another are grouped (Table 2). From this analysis, four groups are categorized, with all their own characteristics and activities. The first group of respondents has the commonality to enjoy landscape, nature and local culture. The second group of respondents takes part in sport activities, takes time for themselves and enjoys the sun and water. The third group shares experiences through social media, enjoys healthy food and lifestyle, goes shopping, takes time for partner, friends and or family and experiences a variety of culinary offerings. Finally, the fourth group participates in nightlife and meets new people.

Table 2. Groups of tourists with their activities in Canggu

\begin{tabular}{|c|c|c|c|}
\hline $\begin{array}{l}\text { Group } 1 \\
\text { - Enjoying landscape and } \\
\text { nature } \\
\text { - Enjoying local culture }\end{array}$ & $\begin{array}{l}\text { Group } 2 \\
\text { - Taking part in sports } \\
\text { activities } \\
\text { - Taking time for } \\
\text { themselves } \\
\text { - Enjoying the sun and } \\
\text { water }\end{array}$ & $\begin{array}{l}\text { Group } 3 \\
\text { - Sharing experiences through } \\
\text { social media } \\
\text { - Enjoying healthy food and lifestyle } \\
\text { - Going shopping } \\
\text { - Taking time for partner, friends } \\
\text { and/or family } \\
\text { - Experiencing a variety of culinary } \\
\text { offerings }\end{array}$ & $\begin{array}{l}\text { Group } 4 \\
\text { - Participating in } \\
\text { nightlife } \\
\text { - Meeting new } \\
\text { people }\end{array}$ \\
\hline
\end{tabular}


While taking the questionnaire, short informal interviews have been done with either the respondents or their travel parties. The main focus of these informal interviews was on how often they had visited the Canggu area before, so if the tourist was a repeat visitor, and to gain in-depth information on why they had chosen the Canggu area for their holiday, which is directly related to the questionnaire item about the activities they took part in.

From these short informal interviews, the main finding was that all questioned tourists fit into one of the two following categories: 1) The tourist is a return visitor to Canggu/has been coming to Canggu before 2016 but is starting to dislike the developments taking place in the area and is not planning on returning or 2) the tourist is a first time visitor/has not been to Canggu area before 2016 and is very enthusiastic about the area and is planning on returning. Furthermore, the tourists that have mentioned option 1 as their case, also talked about how the quietness, landscape, nature and the local culture has always been their reason to come to the Canggu area and how it is now disappearing. It was stated by this group that the Canggu area is becoming crowded.

From participant observations, three major outcomes were important for the analysis of the tourist profile of the Canggu area. Within these participant observations, the researchers took part in the activities as if they were tourists, in co-working spaces, cafés and restaurants, to seek an understanding of the behaviour of these tourists in different locations.

First, the presence of working visitors was significant to this research. These visitors stayed at the location for a longer period of time, not just to eat or drink. The working visitors seem to be foreigners, and all brought their laptops to work. Another type of visitor was the type of tourist for whom food and social media played a big role. These types of tourists often made healthy food choices and took pictures of their food. Also, many videos on social media were taken and many of these types of visitors used their phones for long periods of time during their visit. Then, the last type observed were surfers, arriving on their motorbikes with a surfboard. These surfers showed a different lifestyle than the previously mentioned group of tourists where Instagram and healthy food played a role. Surfers did not pay attention to nutrition as much and also were in a hurry to eat and get back on their motorbikes.

Different interviewees held different opinions about the demand in the Canggu area. First, interviewees 7, 8 and 18 all mentioned that many Instagrammers visit the Canggu area and specifically their business. They take pictures of their products and share them with the rest of the world. Furthermore, interviewees 6 and 9 both mentioned seeing working visitors in their enterprise. These are businesspeople who need a working space outside, other than their homes. Also, health conscious and vegan customers were mentioned as seen by interviewee 3. Finally, both interviewee 8 and 12 mentioned seeing a surfer type in the Canggu area. They are characterized as being laid back and alternative backpackers.

The three field research methods used within this research, the tourist survey, (participant) observations and interviews, formed the base of triangulated data about the visitor profile of the Canggu area. The results show that the visitor profile in the Canggu area can be divided into four types of profiles: the authenticity seekers, the active travellers, the multi experiencers and the networkers. When combining all field research methods, the tourist survey, the observations and the interviews, the data shows there is a shift in the 
market taking place at this moment. In the Canggu area, there is a shift from the traditional markets towards new market segments. First, the traditional market segments are based on the characteristics of nature, local culture, intermediate or advanced surfers, less crowded areas and with a focus on individualism. Now, the market is shifting towards new market segments with characteristics such as social media sharing, healthy food and lifestyle, beginner surfers, shopping, multi experiences, bars and cafés and with a focus on the mass market. At the moment of doing field research, it has shown that the traditional market is still present at the destination, although it is declining.

\section{The preferable future}

The overlapping issue in the Canggu area is the rapid change in a short period of time. Therefore, for many community and development stakeholders, finding a balance between economic growth and culture preservation will be the biggest challenge; thus is their preferable future. It can be concluded that the preferable future of the Canggu area is to keep it as successful as it already is with controlled growth. Developments are already happening and cannot always be influenced, but keeping the Canggu area together as one is something that is preferred by both the stakeholders and the visitors. The loss of culture is something that is preferred to be avoided in the Canggu area and growth is preferred to be controlled by responsible parties, such as the banjars. The Canggu area prefers to avoid becoming like other uncontrolled destinations in Bali, such as Kuta and Seminyak, which includes a massive change in the visitor profile and in the atmosphere of the area itself. Furthermore, MSEs in the area wish for positive economic development, in which innovators, adapters and survivors alike can sustain their businesses and thrive without becoming a mass-tourism destination.

The area of Canggu as a whole is responding to trends or is creating trends that attract specific kinds of tourists. These trends can change or evolve the future of MSEs in the area of Canggu in the way that the community is hoping for.

In the past conscious food choices such as dairy alternatives and meat substitutes were noticeable as global trends. The amount of people worldwide identifying as vegans has increased over the past years in many countries (Ipsos MORI, 2016; News online, 2017; Smith, 2017). Google Trends points out that there has been an enormous increase in the interest in veganism from 2004 to 2018 (Google Trends, 2018). A survey made by Nielsen Global (2015) shows that one third of their respondents is willing to pay a higher price for organic products. Generally, a tendency towards conscious food choices is recognizable in Bali. In travel blogs as well as on social media and in tour guides, Canggu is mentioned as one of the trendiest hotspots for travellers with a vegan and organic lifestyle (Czebotar, 2017; George, 2018).

Then, in Canggu, businesses seem to be willing to run responsibly. Various MSEs were presenting ideas of their Corporate Social Responsibility (CSR) such as producing environmentally friendly clothing, supporting local manufactures and establishing projects that help poor communities outside of Bali (interviewees 7, 9, 18). Tourists seem to go along with the trend of living a responsible lifestyle. They pay attention to what they consume and experience. The researchers heard tourists asking questions to waitresses and vendors in 
supermarkets about the ingredients of meals and drinks. On top of that, $28 \%$ of the tourists surveyed found healthy food and lifestyle generally important while travelling.

A digital nomad is an employee or entrepreneur who uses digital technologies for working while being location-independent (Investopedia, 2018). These mostly young professionals seek holistic freedom in work, leisure and travel (Reichenberger, 2017). The environment in the Canggu area is made for digital nomads. The Nomad List, which is an online platform presenting a list of cities that are matching the digital nomad lifestyle based on indicators such as cost of living and quality of living, shows that the area of Canggu scores 4.84 out of 5 overall (Levels, 2018). During the informal interviews, some tourists mentioned the high work-life-balance, that manifests in living in a villa in a calm surrounding, having opportunities to surf, doing yoga and eating healthy food as well as working in one of the coworking spaces. Additionally, digital nomads benefit from each other by making use of the strong community offered by co-working spaces.

As smartphones become an integrated part of our lives, the time people spend on social media has increased enormously. The fear of missing out, also known as FOMO, is a social anxiety that people can feel about missing out on activities that might take place elsewhere. Especially amongst the younger generation there is a desire to stay connected constantly to what others are doing (Przybylski, Murayama, DeHaan \& Gladwell, 2013). In Canggu, restaurants use this technique by posting pictures of their perfect looking smoothie bowls on Instagram (interviewee 3,6, 8), hostels promote their pool parties in Facebook groups (interviewee 12) and yoga schools advertise for the best Ashtanga yoga teacher in town on their websites (interviewee 19). Newspapers and bloggers trigger tourists to come to Canggu and put photos of infinity pools on Instagram or try to surf in one of the most famous surf areas in Bali (World Travel Asia, 2017; Wandering Class, 2017).

Already in 1999, Pine and Gilmore offered the experience economy as a new way to connect businesses with customers. In fact, the idea of creating experiences to leave a memorable impression is now more relevant than ever (Pine \& Gilmore, 1999). More businesses are responding by explicitly designing and promoting the experience economy. A leading example in Canggu is one of the first established cafés (interviewee 8). People can interact by participating in skate competitions and live tattooing. Interviewees 7 and 15 have a strategy that is aiming to create an experience economy. The restaurant is planning on engaging with customers by letting them decide which direction of social responsibility they should chose.

The forces that impact developments in the Canggu area can be divided into internal and external forces. Internal forces are improved accessibility and the arrival of medium and large organizations. The target of 20 million tourist arrivals in Indonesia and 7 million tourist arrivals in Bali and the loss of rice fields through increased taxes are forces that impact from outside of the research area.

Several interviewees agreed on the fact that parts of the Canggu area are not easily accessible to all visitors. Interviewees mentioned that the accessibility to some businesses inside the Canggu area is in need of improvement, as shortcut roads have been closed, parking or walking space is not available in some parts of the area. Especially businesses that are not located along the busy roads, such as Batu Bolong or Pererenan, wish for their 
locations to be easier to reach. Since the road map in Canggu is organized in a caterpillar way (one main road with many crossing roads that end not connecting to another road), shortcut roads are vital for the accessibility of some. Often, the quality of these shortcuts is very low; some have been closed down already. Interviewee 5 explains how road congestion is increasingly becoming problematic. According to Coconuts Bali (2016) and Interviewee 12, a change is going to take place. An extension of sunset road that will connect Kuta and Canggu in the future and might allow for an improved traffic flow between Kuta, Seminyak, and Canggu and might attract more people into the research area.

In the past years, Canggu has changed from a small village with just a few surfers visiting to a tourist attraction. This development has not gone unnoticed by bigger hotels and chains as well as franchised food outlets. In 2018 Como Uma, a luxury resort, opened up in Echo Beach, and an InterContinental is currently under construction. There are plans for a Trump Hotel to be built in the Canggu area, with the view on Tanah Lot (Wärterlin, 2017). Plenty of brand names, such as RipCurl, Billabong, and Globe have already opened shop in Canggu. Furthermore, interviewees 7 and 21 mentioned that currently a McDonalds and a Cinema are being planned on the parking lot of Deus Ex Machina, one of Canggu's famous food and beverage outlets. For many interviewees, the above-mentioned changes raise concern about what Canggu will look like in the future. While interviewee 8 believes that these developments will bring in a different kind of visitor, which the community is not entirely happy about, Interviewee 18 and interviewee 7 think that the moving in of chains can alter the structure of MSEs and change the network they have built up amongst one another. Even more pessimistic, Interviewee 21 believes that these changes are "the beginning of the end".

As mentioned by The Worldfolio (2017), Indonesia's minister of Tourism has decided to set the target for 20 million tourist arrivals in Indonesia by 2019. For most tourists, Bali still dominates the average visitor's itinerary and accounts for approximately $45 \%$ of Indonesia's total tourist numbers. This is supported by The Jakarta Post (2017). It is stated that the Ministry of Tourism in Indonesia set the target to attract 7 million foreign tourist arrivals in Bali in 2019. A budget of almost 100 billion Indonesian Rupiah, which is equal to \$7.3 million USD, has been set to boost the promotion of the island. This development can influence Bali and therefore Canggu as an external force.

Bali's rice fields have become in real danger. The Balinese landscape is becoming so popular for tourism that farmers are selling their rice fields to developers for new tourism developments. Since the entire farming system is integrated, neighbouring farms have to deal with increasing taxes, because of the loss of rice production. This puts an increased pressure on farmers and could cause the system to collapse (Finlayson, 2013). This data is supported by the interviews in the Canggu area. As interviewee 7 mentions, many rice fields around their business are already sold or are for sale because of tourism developments. Also, interviewee 8 mentions that the changes in the taxation system makes operating rice fields more expensive, which results in the loss of many fields. Finally, interviewee 15 states that he expects the rice fields to disappear in the future. This development can have major influence on the Canggu area. The accessibility to nature and local culture, which is now still one of the motivations for travelers to come to Canggu, might disappear. 


\section{Recommendations}

MSEs that have been interviewed for this report mostly had a vision of what they want the area of Canggu to look like in the future. Yet, current developments and trends might endanger this preferable future. The researchers of the report attempted to listen closely to what MSEs in Canggu would see as most beneficial for their own businesses as well as for the area as a whole in order to provide effective interventions, that are likely to have a positive effect on the wishes for the preferred future of the destination.

During the research process it became apparent that successful businesses, whether they are survivors, adapters or innovators, have one thing in common: they are all part of a network. Some networks consist of family bonds, others are comprised of relationships between a few businesses, and occasionally they are rooted in the community itself. These networks provide them with stability and help in times of need, but rarely overlap. Interviewee 8 explained that from her perspective, a strong relationship between her and other businesses with similar structures exist. She described that they do not see each other only as competitors, but also as friends, who help each other out. If it was up to her, new enterprises who open up in the area would introduce themselves to the existing ones, which happens less and less.

The researchers believe that it would be beneficial for the MSEs in the Canggu area to create a strong bond amongst one another in which each group of stakeholders can benefit and learn from the others. This bond could be established between the already existing networks to form a larger, encompassing network that will make MSEs more likely to withstand outside forces and undesired developments. Even though the researchers would aim for creating a network amongst all the different kinds of enterprises, the purpose is not to change the way of each business's operation. It is important to point out that although the businesses can learn and benefit from another, all groups of stakeholders have their place in the supply economy of Canggu. Survivors will and should not be turned into innovators and vice versa. What the proposed interventions are likely to help with, is that each group of stakeholders can make the best out of their position within the area. Furthermore, the researchers believe that it is likely to reach the preferable future if proposed interventions are being followed. The researchers believe that MSEs in the area are adaptive enough to make proposed interventions a reality. Furthermore, many of them are driven by a strong love for the area of Canggu. At the moment, Canggu has a suitable size and atmosphere in which it is still possible to create a network amongst a large number of MSEs. Furthermore, the researchers believe that the attending markets would be likely to support the endeavours to form a network, since many tourists, expats and locals have a sense of a responsible lifestyle. The researchers believe that in the context of the responsible lifestyle way of thinking, it could benefit innovators and even larger organizations to exist in a community of helping one another. It could be part of a corporate social responsibility strategy and used as a marketing tool at the same time. Since all types of businesses are vital to the Canggu area, a tight-knit, mutually beneficial community, so the researchers believe, would make it less likely for businesses to move to another area. 
In the following section, we propose the possible effective interventions, which consist of three steps.

In fact, all groups of stakeholders operate at different stages and have established various strengths. A programme where these skills can be shared in a network environment will be beneficial for each of the businesses. For example, the innovator's strength lies in economic knowledge, while survivors can share their knowledge about culture.

The programme can be organized in a way that entrepreneurs come together on a regular basis, hosted by a business in the Canggu area. In the implementation process, a business that can function as the initiator needs to be found. It is recommendable that this enterprise has suitable facilities to welcome other entrepreneurs and is willing to hold events in said facilities. A likely candidate to function as the initiator, has already been found in the research process. This business is led by a woman who has a very well-established network within the community. She is being trusted by locals and foreigners alike and has great understanding of all stakeholders as well the banjar, which makes her the ideal entrepreneur to launch the programme. Furthermore, said business is so successful and stable that economic growth is not seen as the main goal anymore. It leads to a willingness on her side to help others and to strengthen the area of Canggu as a whole. After the inauguration of the programme, a suggestion for a long-term vision is that the events can be held in a rotative system through other enterprises' venues.

If businesses in the area of Canggu cooperate and form a network, following the belief that they are stronger together, it is more likely that undesired outside influence will change Canggu for the worse. If all enterprises work together and Canggu is promoted to tourists as one, it is more likely that the desired customer profile will be attracted. In order to create a bond in which this is possible, the researchers propose the creation of a circular model. This model includes variables such as trust, knowledge, self-efficacy, competence, and performance (Clegg \& Spencer, 2010; Manniche, Larsen, Broegaard \& Holland, 2017) that makes businesses be able to thrive. Firstly, the researchers believe that the creation of a sense of identity and trust could help the community in Canggu to achieve a stronger strategic position in the future. Therefore, a possible strategic intervention could be not only to network between one another, but also to engage in creative activities and product development. Interviewee 3 mentioned that he believed that the creation of new products such as cooking, woodcarving, and smoothie bowl classes could be set up. Moreover, a community project in which members of the created network design graffiti or a landmark together could help to give the MSEs in Canggu a sense of identity as one. Through this sense of identity, a sense of mutual trust is likely to be established. Knowledge production and a sense of self-efficacy could be promoted to the above mentioned educational and sharing programme. In an inclusive, all stakeholder encompassing community like this, where competencies of each type of business are valued, enterprises are more likely to see their own strengths. Which, in turn, will have positive effects on their strategic position in the future. Ultimately, so the researchers believe, through educational programmes and knowledge sharing, the performance of each stakeholder can be improved. Researchers think that high quality jobs and constant innovation will make the position of MSE's 
strategically stronger and help business to brace for any future scenario. To truly empower MSEs in the Canggu area, it would be beneficial to break down divisions between sectors, including residents, businesses and social accelerators alike.

As explained before, Bali has a special characteristic of a social and cultural community, which is called banjar, in every area. Like other destinations, the Canggu area has some banjars that help to preserve their traditions, culture and social relations. Every banjar has their own plan with the purpose of creating a sustainable life condition for their area as the "social and cultural keeper". Based on the interviews, the banjar has a strong social power to manage the system and relations between every enterprise as well as locals in the Canggu area. The banjar can play a big role as a mediator for every stakeholder group to establish a community. This community should invite every categorized stakeholder to have a common goal for a better Canggu area, that directly and indirectly will help all tourism stakeholders to improve their quality and increase their profits in the future. In this case, survivors which are dominated by the locals will have in interest in taking part in this exchange to learn new abilities, to maintain local respect, especially if the banjar appreciates the measures. Adaptors and innovators will also appreciate this step as they know that becoming more involved with locals and earning their approval is key to long-term business success in Canggu. However, in the process of building a community, the banjar also have to internalize the purpose of this community which is related with education as an investment for every stakeholder. Ultimately, the researchers' advice to the banjar is to share their tourism master plan for Canggu, so that every stakeholder can gain an understanding of what will happen in the future. This condition will further the process of knowledge sharing between every stakeholder for their own business strategy and also how they can adapt with the idea of future Canggu area. Then, the collaborations between every stakeholder with the managing influences from banjar will help to implement the common goal of Canggu area.

\section{Conclusion}

All stakeholders in the area of Canggu have different roles and responsibilities to preserve the identity of Canggu. It is apparent that almost all stakeholders lack knowledge in one way or another. While some entrepreneurs have a better understanding of general economics, business strategies that can foster success and professional skills that are needed to archive a stable operation, others have a better socio-cultural knowledge. Through a collaboration of all stakeholders, this gap can be bridged, and a heightened sense of community can be established. The researchers conclude, that this will reduce the tension between single businesses in the Canggu area and help strengthen the area as a whole. In the end, every stakeholder cannot stand alone and run their business without direction. If this happens, then Canggu will lose its unique selling point. This highlights the importance of the DMO, that can give direction in the sense of an overall strategy but that can also assure all stakeholders of the importance of their respective roles within the community. Finally, the authors believe the key to success of the sustainability of Canggu Area lies in the notion that "sharing is caring". 


\section{References}

Bali Tourism (2017). Canggu. Retrieved from http://www.balitourism.nl/canggueng.htm

Burgess, R. G. (1984). In the field: An introduction to field research. London: Unwin Hyman.

Coconuts Bali (2016). Bali mega toll road plans still drag priority given Kuta Tanah Lot route. Retrieved from https://coconuts.co/bali/news/bali-mega-toll-road-plans-still-drag-priority-given-kutatanah-lot-route/

Clegg, C. \& Spencer, C. (2007). A circular and dynamic model of the process of job design. Journal of Occupational and Organizational Psychology, 8o(2), 321-339. doi: 10.1348/096317906x113211

Czebotar, L. (2017). Vegan guide to Canggu. Retrieved from http://lostisthenewfound.com/veganguide-to-canggu/

Digital Nomad Lifestyle (2018). Our Bali workation: Is Bali good for digital nomads? Retrieved from http://www.fulltimenomad.com/bali-digital-nomads/

Finlayson, R. (2013). Balis world heritage rice field system on brink of collapse. World agroforestry centre. Retrieved from http://blog.worldagroforestry.org/index.php/2013/08/30/balis-world-heritagerice-field-system-on-brink-of-collapse/

George, Y. (2018). Vegan auf Bali: Geheimtipps für Canggu, ubud und seminyak. Retrieved from https://indojunkie.com/vegan-bali-tipps

Google Trends. (2018). Veganism. Retrieved from https://trends.google.com/trends/explore?date=all\&q=\%2Fm\%2F07_hy

Government of Bali. (2010). Bali dan Pariwisata. Retrieved from http://www.baliprov.go.id/Bali-danPariwisata

Hewett, J. (2017). The Bali hot spots you'll want to keep secret. Retrieved from http://www.heraldsun.com.au/travel/world/asia/the-bali-hot-spots-youll-want-to-keepsecret/news-story/0689e25fa680c74e755242acfoccof6a

Indonesian Ministry of Industry (2018). Pengertian Usaha Mikro, Kecil, dan Menengah. Retrieved from http://bdisurabaya.kemenperin.go.id/question/pengertian-usaha-mikro-kecil-dan-menengahumkm/

Investopedia (2018). Digital Nomads. Retrieved from https://www.investopedia.com/terms/d/digitalnomad.asp

Ipsos MORI (2016). Vegan society poll. Published by Ipsos MORI. Retrieved from https://www.ipsos.com/ipsos-mori/en-uk/vegan-society-poll

Levels, P. (2018). Canggu, Bali. Retrieved from https://nomadlist.com/canggu-bali-indonesia

Manniche, J., Larsen, K., Broegaard, R. \& Holland, E. (2017). Destination: A circular tourism economy. A handbook for transitioning toward a circular economy within the tourism and hospitality sectors in the South Baltic Region. Nexoe, Denmark: Centre for Regional Development Fund. Retrieved from https:/circulareconomy.europa.eu/platform/sites/default/files/cirtoinnohandbook_eng-rev.-4.pdf

Morgan, K. \& Berkmoes, R. V. (2017). Lonely planet Bali \& Lombok. Dublin: Lonely Planet.

News online (2017). Number of vegetarians in Portugal rises by 400 percent in 10 years. Retrieved from http://theportugalnews.com/news/number-of-vegetarians-in-portugal-rises-by-400-percentin-10-years/43482

Nielsen Global (2015). Nielsen's global health \& wellness survey: We are what we eat. Healthy eating trends around the world. Retrieved from https:/www.nielsen.com/wp- 
content/uploads/sites/3/2019/04/Nielsen20Global2oHealth2oand2oWellness2oReport2020January202015-1.pdf

Pine, B. P. \& Gilmore, J. H. (1999). Welcome to the experience economy. Boston, Massachusetts: Harvard.

Przybylski, A., Murayama, K. DeHaan, C. \& Gladwell, V. (2013). Motivational, emotional, and behavioral correlates of fear of missing out. Computers in Human Behavior, 29(4), 1841-1848. doi: 10.1016/j.chb.2013.02.014

Reichenberger, I. (2017). Digital nomads. A quest for holistic freedom in work and leisure. Annals of Leisure Research, 21(3), 364-380. doi: 10.1080/11745398.2017.1358098

Rid, W., Ezeuduji, I. O. \& Pröbstl-Haider, U. (2014). Segmentation by motivation for rural tourism activities in The Gambia. Tourism Management, 40, 102-116. doi: 10.1016/j.tourman.2013.05.006

Salkind, N. J. (Ed.) (2010). Encyclopedia of research design (Vols. 1-0). Thousand Oaks, CA: SAGE Publications, Inc.

Smith, S. (2017). Top trends in prepared foods 2017: Exploring trends in meat, fish and seafood; pasta, noodles and rice; prepared meals; savoury deli food; soup; and meat substitutes. Retrieved from https://www.prnewswire.com/news-releases/top-trends-in-prepared-foods-2017-exploringtrends-in-meat-fish-and-seafood-pasta-noodles-and-rice-prepared-meals-savory-deli-foodsoup-and-meat-substitutes-300478350.html

The Jakarta Post (2017). Indonesia aims to attract 7 million tourists to Bali in 2018. Retrieved from http://www.thejakartapost.com/travel/2017/12/20/indonesia-aims-to-attract-7-million-touriststo-bali-in-2018.html

Wandering Class (2017). Five reasons why you must travel to Bali, and how it's actually affordable! Retrieved from www.wanderingclass.com/blog/2017/3/23/whybali

The Worldfolio (2017). Setting the stage for 20 million tourists by 2019. Retrieved from http://www.theworldfolio.com/news/setting-the-stage-for-20-million-tourists-by-2019-/4239/

Wärterlin, U. (2017). Trump und die Dämonen. Umstrittenes Hotelprojekt auf Bali. Handelsblatt. Retrieved from http://www.handelsblatt.com/my/finanzen/immobilien/umstritteneshotelprojekt-auf-bali-donald-trump-und-die-daemonen/20091162.html?ticket=ST-2710150wgLnZAvskK1OBBoQkcTy-ap2

World Travel Asia. (2017). The Bali hot spots you'll want to keep secret. Retrieved from http://www.news.com.au/travel/world-travel/asia/the-bali-hot-spots-youll-want-to-keepsecret/news-story/f20c4703a7fffoedf15a3722dcoabea3

INGA KLUDZEWEIT is an alumnus of Breda University's Master in Tourism Destination Management programme and has worked as Junior Consultant in several destination development projects in South East Asia and Mozambique. Currently she is developing customer relations as a Key Account Manager at FTI Touristik GmbH. Institutional postal address: Tourism Department, Breda University of Applied Sciences, Mensinkweg 78, 7442 TG Nijverdal, Netherlands.

TIMOTI TIRTA received his Bachelor degree in Sociology from Universitas Indonesia in 2013 and Masters degree in Tourism Destination Management from Breda University of Applied Sciences in 2018. He works as a social researcher, focusing on tourism studies and the socio-cultural study of Eastern Indonesia. Institutional postal address: Tourism Department, Breda University of Applied Sciences, Mensinkweg 78, 7442 TG Nijverdal, Netherlands. 
THANIA KAMARGIANNIS received her Masters degree in Tourism Destination Management from Breda University. After focusing her research on startups in Tourism, she delved further into the world of young businesses to work as a communications assistant. Institutional postal address: Tourism Department, Breda University of Applied Sciences, Mensinkweg 78, 7442 TG Nijverdal, Netherlands.

ELLIS MIDDELKAMP holds a degree in Tourism Destination Management (MA) and Tourism \& Leisure Management (BA). She currently works as a researcher in various (international) projects in the field of tourism at Breda University of Applied Sciences. Besides this, Ellis works in marketing at Enschede Promotie, where she is responsible for setting up a new city marketing brand among students. Institutional postal address: Tourism Department, Breda University of Applied Sciences, Mensinkweg 78, 7442 TG Nijverdal, Netherlands.

Submitted on September 30, 2019

Accepted on March 06, 2020 